\title{
Penerapan Model Discovery Learning dalam Mengatasi Kecemasan Matematika Siswa SMP
}

\section{IMPLEMENTATION OF MODEL DISCOVERY LEARNING IN OVERCOMING THE STUDENT'S MATHEMATICAL ANXIETY OF JUNIOR HIGH SCHOOL}

\author{
Yayah Umayah ${ }^{1}$ \\ ${ }^{1}$ SMP Negeri 1 Ciruas Kabupaten Serang, yayahumayah280@gmail.com
}

\begin{abstract}
Abstrak
Penelitian ini bertujuan untuk mengetahui sejauh mana kreativitas peserta didik pada konsep bilangan melalui model pembelajaran Discovery Learning dalam mengatasi kecemasan matematika di kelas VII D SMPN 1 Ciruas Kabupaten Serang. Objek penelitian terdiri dari 32 siswa, dan dilaksanakan dengan menjalin kemitraan atau kolaboratif dengan rekan guru lain sebagai observer. Data yang dikumpulkan data kuantitatif dengan pengolahan data statistik sederhana dan data kualitatif dengan menggunakan instrumen kecemasan matematis. Penelitian Tindakan Kelas ini menggunakan Model John Elliot dimana pelaksanaannya dilakukan melalui dua siklus dan setiap siklus terdiri dari dua kali pertemuan. Adapun hasil yang diperoleh dari penelitian ini menunjukkan bahwa penggunaan model pembelajaran Discovery Learning dapat menurunkan kecemasan matematis dan meningkatkan kreativitas peserta didik. Hasil belajar siswa yaitu siswa hanya $76 \%$ (24 siswa) siswa yang mencapai KKM $\geq 70$ pada siklus I sedangkan pada siklus II mencapai KKM $\geq 70$ sudah tercapai yaitu 90\% (29 siswa). Pada kecemasan matematis siklus I terjadi kecemasan matematis rata-rata masih 71 berdasarkan hasil refleksi dan siklus II terjadi penurunan kecemasan matematis menjadi 65, penurunan kecemasan matematis $8,5 \%$.
\end{abstract}

Kata kunci: Discovery Learning, Kecemasan Matematis

\begin{abstract}
The study aims to determine the extent to which the student's creativity in the concept of numbers through the Discovery Learning model in overcoming math anxiety in class VII SMPN 1 Ciruas Kab Serang. The research object consists of 32 students. This research uses John Elliot Model where the implementation is done through two cycles and each cycle consists of two meetings. The results derived from this research show that the use of Discovery Learning models can bring down mathematical anxiety and enhance the creativity of learners. Student learning results are $76 \%$ of students who reach $K K M \geq 70$ on cycle I while the cycle II reaches the KKM $\geq 70$ is reached i.e. $90 \%$. At the mathematical anxiety cycle I had an average mathematic anxiety still 71 based on the results of reflection and cycle II occurred decreased mathematical anxiety to 65, decreased mathematical anxiety by $8.5 \%$.
\end{abstract}

Keywords: Discovery Learning, Mathematical Anxiety 


\section{PENDAHULUAN}

Salah satu upaya untuk mencapai tujuan pendidikan nasional dan meningkatkan keterampilan abad 21, perlu dikembangkan pembelajaran dimana baik guru maupun siswa bersama-sama menjadi pelaku terlaksananya tujuan pembelajaran. Tujuan pembelajaran ini akan mencapai hasil yang optimal, apabila pembelajaran dapat menciptakan dan mempertahankan kondisi yang menguntungkan bagi siswa (Rohani, 2010). Selanjutnya Rohani juga menyatakan bahwa usaha guru dalam menciptakan kondisi pembelajaran yang efektif adalah pembelajaran yang mampu melibatkan seluruh siswa secara aktif. Untuk mengembangkan proses pembelajaran di atas salah satu model pembelajaran yang bisa digunakan model pembelajaran penemuan/discovery learning. Dalam pembelajaran discovery menurut Amir (2015) belajar melalui keterlibatan aktif dengan konsep-konsep dan prinsip-prinsip dalam memecahkan masalah, dan guru mendorong siswa untuk mendapatkan pengalaman dengan melakukan kegiatan yang memungkinkan siswa menemukan prinsip-prinsip untuk diri mereka sendiri.

Penelitian yang dilakukan Anis (2017) menyatakan proses pembelajaran dengan menggunakan model Discovery Learning dapat meningkatkan kemandirian peserta didik yaitu Kepercayaan diri, kedisiplinan dan inisiatif, Rasa tanggung jawab dan motivasi dan hasil belajar siswa. Strategi pembelajaran discovery merupakan strategi pembelajaran yang dasar filosofinya konstruktivisme, teori konstruktivisme yang dikembangkan oleh Peaget (Sani, 2016) menekankan pembelajaran pada proses belajar, bukan mengajar. Dimana pembelajaran kontruktivisme memberi kesempatan pada siswa untuk membangun pengetahuan dan pemahaman baru yang didasarkan pada pengalaman yang nyata. Teori ini berpandangan bahwa belajar merupakan suatu proses, bukan menekankan hasil. Hal ini sejalan dengan strategi discovery Learning, dimana siswa membangun sendiri pengetahuannya. Pembelajaran discovery dirancang dengan tujuan untuk mengembangkan siswa supaya memiliki kemampuan ilmiah, dan juga memotivasi melakukan keterlibatan langsung dalam proses pembelajaran. Dalam pembelajaran discovery siswa terlibat secara mental dan fisik untuk memecahkan masalah yang diberikan oleh guru. Discovery memberikan siswa pengalaman-pengalaman belajar nyata dan aktif. Siswa dilatih bagaimana memecahkan masalah, membuat keputusan, dan memperoleh keterampilan.

Pendekatan discovery menurut Syaiful Sagala (2013) yakni : (1) merumuskan masalah untuk dipecahkan siswa; (2) menetapkan jawaban sementara atau lebih dikenal dengan istilah hipotesis; (3) siswa mencari informasi, data, fakta yang diperlukan untuk menjawab permasalahan/hipotesis; (4) menarik kesimpulan jawaban atau generalisasi; dan (5) mengaplikasikan kesimpulan/generalisasi dalam situasi baru.

Menurut Kusnandar (2007) keunggulan penggunaan strategi pembelajaran discovery adalah memacu keinginan siswa untuk mengetahui, memotivasi mereka untuk melanjutkan pekerjaan sehingga mereka menemukan jawaban dan siswa belajar menemukan masalah secara mandiri dengan memiliki keterampilan berpikir kritis.

Sedangkan menurut Heriawan (2012) langkah-langkah dalam pembelajaran discovery adalah sebagai berikut: (1) identifikasi kebutuhan siswa; (2) seleksi pendahuluan terhadap prinsip-prinsip, pengertian konsep dan generalisasi pengetahuan; (3) seleksi bahan, problema/ tugas-tugas; (4) membantu dan memperjelas tugas/problema yang dihadapi siswa serta peranan masing- 
masing siswa; (5) mempersiapkan kelas dan alat-alat yang diperlukan; (6) Mengecek pemahaman siswa terhadap masalah yang akan dipecahkan; (7) Memberi kesempatan pada siswa untuk melakukan penemuan; (8) membantu siswa dengan informasi/data jika diperlukan oleh siswa; (9) memimpin analisis sendiri (self analysis) dengan pertanyaan yang mengarahkan dan mengidentifikasi masalah; (10) merangsang terjadinya interaksi antara siswa dengan siswa; (11) membantu siswa merumuskan prinsip dan generalisasi hasil penemuannya.

Ada beberapa keuntungan atau keunggulan dalam belajar discovery menurut Sumarmo (Sumarmo, 2015) yaitu: (1) pengetahuan bertahan lama dan mudah diingat; (2) hasil belajar discovery mempunyai efek transfer yang lebih baik dari pada hasil lainnya; (3) secara menyeluruh belajar discovery meningkatkan penalaran siswa dan kemampuan untuk berpikir bebas. Secara khusus belajar penemuan melatih keterampilan-keterampilan kognitif siswa untuk menemukan dan memecahkan masalah tanpa pertolongan orang lain.

Model pembelajaran Discovery Learning dalam mengatasi kecemasan matematika, kecemasan matematika dapat terjadi pada setiap saat pada diri siswa baik yang memiliki kemampuan matematis tinggi atau rendah. Seringkali kecemasan ini muncul secara mendadak ketika siswa belajar matematika. Ketika kecemasan matematis itu sudah berlebihan, maka akan menghambat siswa dalam belajar dan mengembangkan kemampuan matematisnya. Hal ini berarti kecemasan matematis pada diri siswa sangat mengkhawatirkan. Kecemasan Matematis, Selalu dialami oleh siswa manakala berhadapan dengan mata pelajaran matematika. Ungkapan-ungkapan siswa yang secara spontanitas menjawab apabila ditanya mengenai matematika, bahwa mata pelajaran ini : "menakutkan", "sulit", "rumit", "membuat deg-degan", dan lain sebagainya, mencerminkan bahwa matematika secara umum dinilai oleh siswa" dibenci" (Greshman, 2010).

Hal ini sejalan dengan dalam penelitiannya mengungkapkan bahwa mendorog siswa untuk berkelompok, merupakan salah satu strategi yang dapat membantu siswa mengatasi kecemasan matematis. Dengan bekerja secara berkelompok, akan saling membantu mengatasi kesulitan mereka. Penelitian ini bertujuan untuk mengetahui pengaruh model Discovery Learning sejauh mana kreativitas peserta didik pada konsep bilangan melalui model pembelajaran Discovery Learning dalam mengatasi kecemasan matematika di kelas VII D SMPN 1 Ciruas Kabupaten Serang terhadap kecemasan matematis peserta didik dengan tegang dan cemas yang dipengaruhi dengan berbagai cara ketika menyelesaikan soal matematika.

\section{KAJIAN TEORI}

\section{Discovery Learning}

Salah satu strategi pembelajaran yang memberikan kesempatan bagi siswa untuk menemukan sendiri pengetahuannya serta berperan aktif dalam pembelajaran sehingga mampu memahami konsep dengan baik dan mengembangkan kemampuan berpikir kritis adalah strategi pembelajaran penemuan (Discovery). Strategi pembelajaran discovery adalah suatu rangkaian kegiatan yang melibatkan kegiatan belajar secara maksimal seluruh kemampuan siswa untuk mencari dan menyelidiki secara sistematis, kritis, logis, analitis, sehingga mereka dapat merumuskan sendiri penemuannya dengan penuh percaya diri.

Model pembelajaran discovery learning diartikan sebagai prosedur mengajar yang mementingkan pengajaran perseorang, memanipulasi objek 
sebelum sampai pada generalisasi. Sedangkan Bruner (Amir, 2015) menyatakan bahwa anak harus berperan aktif didalam belajar. Lebih lanjut dinyatakan, aktivitas itu perlu dilaksanakan melalui suatu cara yang disebut discovery. Discovery yang dilaksanakan siswa dalam proses belajarnya, diarahkan untuk menemukan suatu konsep atau prinsip.

Model pembelajaran discovery menurut Fasco (Yusmanto, 2013) menyatakan model discovery learning adalah salah satu model pembelajaran yang melibatkan partisipasi aktif siswa dalam mengeksplorasi dan menemukan sendiri pengetahuan mereka serta menggunakannya dalam pemecahan masalah. Sedangkan pendapat yang dikemukakan Pavlov (Mentari, 2015) dalam teorinya menyatakan bahwa belajar merupakan proses perubahan yang terjadi karena adanya syarat-syarat yang menimbulkan reaksi dengan adanya latihan serta pengulangan. Adapaun tahapan yang ditempuh dalam melaksanakan pendekatan discovery menurut Syaiful Sagala (Sagala, 2013) yakni : (1) merumuskan masalah untuk dipecahkan siswa; (2) menetapkan jawaban sementara atau lebih dikenal dengan istilah hipotesis; (3) siswa mencari informasi, data, fakta yang diperlukan untuk menjawab permasalahan/hipotesis; (4) menarik kesimpulan jawaban atau generalisasi; dan (5) mengaplikasikan kesimpulan/generalisasi dalam situasi baru.

Sedangkan menurut Scuhman (Heriawan, 2012) langkah-langkah dalam pembelajaran discovery adalah sebagai berikut: (1) identifikasi kebutuhan siswa; (2) seleksi pendahuluan terhadap prinsip-prinsip, pengertian konsep dan generalisasi pengetahuan; (3) seleksi bahan, problema/ tugas-tugas; (4) membantu dan memperjelas tugas/problema yang dihadapi siswa serta peranan masingmasing siswa; (5) mempersiapkan kelas dan alat-alat yang diperlukan; (6) Mengecek pemahaman siswa terhadap masalah yang akan dipecahkan; (7) Memberi kesempatan pada siswa untuk melakukan penemuan; (8) membantu siswa dengan informasi/data jika diperlukan oleh siswa; (9) memimpin analisis sendiri (self analysis) dengan pertanyaan yang mengarahkan dan mengidentifikasi masalah; (10) merangsang terjadinya interaksi antara siswa dengan siswa; (11) membantu siswa merumuskan prinsip dan generalisasi hasil penemuannya.

Ada beberapa keuntungan atau keunggulan dalam belajar discovery menurut Sumarmo (Sumarmo, 2015) yaitu: (1) pengetahuan bertahan lama dan mudah diingat; (2) hasil belajar discovery mempunyai efek transfer yang lebih baik dari pada hasil lainnya; (3) secara menyeluruh belajar discovery meningkatkan penalaran siswa dan kemampuan untuk berpikir bebas. Secara khusus belajar penemuan melatih keterampilan-keterampilan kognitif siswa untuk menemukan dan memecahkan masalah tanpa pertolongan orang lain.

Peran guru dalam pembelajaran discovery menurut Ahmad Rohani (Rohani, 2010) hanyalah sebagai fasilitator dan pembimbing atau pemimpin pengajaran yang demokratis, sehingga diharapkan peserta didik lebih banyak melakukan kegiatan sendiri atau dalam bentuk kelompok memecahkan masalah atas bimbingan guru. Selanjutnya Rohani menyatakan untuk dapat menggunakan pendekatan ini diperlukan persyaratan sebagai berikut :

a) Guru harus terampil memilih masalah yang relevan dan sesuai daya nalar peserta didik

b) Guru harus terampil memberi motivasi belajar dan menciptakan situasi pengajaran yang menyenangkan menarik minat peserta didik

c) Tersedia fasilitas dan sumber belajar yang memadai 
d) Terjamin kebebasan kebebasan peserta didik dalam berpendapat, berkarya, dan sebagainya

e) Kesediaan/kesiapan peserta didik untuk partisipasi aktif dalam belajar

f) Guru tak banyak intervensi dalam kegiatan belajar peserta didik.

\section{Kecemasan Matematis}

Kecemasan matematika merupakan perasaan ketegangan, cemas atau ketakutan yang mengganggu kinerja matematika. (Ashcraft, 2002). Seringkali kecemasan yang dialami mahasiswa, mengakibatkan mereka menghindari situasi dan kondisi dalam penyelesaian masalah matematika. Richardson dan Suin (Anita, 2011) menyatakan kecemasan matematika melibatkan perasaan tegang dan cemas yang mempengaruhi dengan berbagai cara ketika menyelesaikan soal matematika dalam kehidupan nyata dan akademik. Tidak hanya keterlibatan mahasiswa terhadap pelajaran matematika di sekolah secara akademik, tapi apapun bentuk permasalahan dalam kehidupan sehari-hari selagi bersentuhan dengan angka, maka mahasiswa akan cemas dan tegang.

Gejala kecemasan matematika berupa berbagai perasaan gelisah, dan merasa kesulitan bernafas ketika mencoba untuk menyelesaikan tugas-tugas matematika Smith (Pleisance, 2010). Ada pula gejala fisiologis serta gejala psikologis yang dialami oleh mahasiswa yang mengalami kecemasan matematika. Gejala fisiologis dapat berupa peningkatan denyut jantung, tangan berkeringat, serta sakit perut dan sakit kepala ringan. Gejala psikologis dapat ditunjukan dengan perasaan tidak berdaya atau butuh bantuan, khawatir, aib, dan perasaan tidak mampu dalam bekerja dengan matematika. Terdapat beberapa penyebab kecemasan matematika, yaitu:

1. Terlalu banyak ceramah (komunikasi satu arah) dan pembelajaran langsung dalam kelas, tapi kurang diskusi.

2. Terlalu banyak belajar teori matematika, tidak praktis dalm kehidupan seharihari.

3. Pengalaman-pengalaman negative dari awal pembelajaran matematika.

4. Sikap negatif terhadap matematika.

5. Terlalu banyak pekerjaan rumah.

6. Kurangnya pengalaman berhasil/sukses dalam matematika.

7. Kurangnya kemampuan metakognitif.

Berdasarkan penyebab kecemasan matematika yang telah dipaparkan di atas, maka dari sanalah guru dapat memulai menyelesaikan penyebab kecemasan matematika tersebut. Guru dapat mengkreasikan pembelajaran yang sehingga tidak satu arah dalam bentuk ceramah saja, dan berusaha memberikan pengalamam yang berhasil dalam matematika kepada mahasiswa.

Kecemasan matematika adalah kejadian yang berasal dari kurangnya rasa percaya diri mahasiswa. Seringnya kecemasan matematika yang dialami dikarenakan keharusan mahasiswa untuk belajar matematika dengan salah satu cara saja ketika mahasiswa memerlukan berbagai modus instruksi untuk belajar (Fox dan Hoffman, 2011). Kejadian ini lumrah terjadi pada pengajaran biasa yang hanya menggunakan satu instruksi saja, meskipun kita ketahui jika setiap mahasiswa itu memiliki kebutuhan yang berbeda-beda. Banyak mahasiswa yang mengalami kecemasan matematika memiliki ketergantungan atas prosedur dalam matematika. Ketika seseorang belajar matematika dengan menghafal prosedur, aturan dan rutinitas tanpa pemahaman yang memadai, maka pelajaran matematika yang dipelajarinya dengan cepat akan lupa dan menimbulkan kepanikan seketika. 
Keterangan ini mengindikasikan behwa kemampuan pemahaman matematika ini sedikit banyak memberikan andil kecemasan matematika dalam diri mahasiswa.

Selain penyebab kecemasan matematika yang patut menjadi perhatian guru, terdapat pula ranah hak mahasiswa yang harus dijaga untuk dipertimbangkan dalam proses pembelajaran. Student's Mathematics anxiety Bill of Rigth atau disebut Rancangan Hak yang dimiliki mahasiswa berkaitan dengan kecemasan matematika tersebut yang terdiri dari 14 item.

1. hak belajar dengan kecepatan mahasiswa sendiri dan tidak merasa bodoh jika lebih lambat dari orang lain.

2. hak mengajukan pertanyaan apa pun yang dimiliki.

3. hak memerlukan bantuan ekstra.

4. hak meminta seorang guru atau tutor untuk mendapatkan bantuan.

5. hak mengatakan saya tidak mengerti.

6. hak untuk tidak mengerti.

7. hak merasa baik tentang diri sendiri terlepas dari kemampuan mahasiswa dalam matematika.

8. hak untuk tidak mendasarkan diri mahasiswa pada keterampilan matematika.

9. hak untuk melihat diri sebagai yang mampu belajar matematika.

10. hak untuk mengevaluasi instruktur matematika dan bagaimana mereka mengajar.

11. hak untuk bersantai.

12. hak diperlakukan sebagai orang yang kompeten.

13. hak untuk tidak menyukai matematika.

14. hak untuk mendefinisikan kesuksesan dalam istilah mahasiswa sendiri. (Davis, 2012)

Hak yang telah diungkap diatas dapat sebenarnya dapat menjadi cara untuk mereduksi kecemasan matematika. Seperti yang dikemukakan Freedman, terdapat sepuluh cara untuk mereduksi kecemasan matematika.

1. mengatasi perasaan negatif terhadap diri sendiri.

2. mengajukan pertanyaan.

3. mempertimbangkan matematika sebagai bahasa asing, oleh karena itu harus dipraktekan.

4. jangan mengandalkan hafalan untuk belajar matematika.

5. membaca buku dan bahan teks matematika.

6. belajar matematika menurut gaya belajar diri sendiri.

7. dapatkan bantuan di hari yang sama saat anda tidak mengerti.

8. belajar matematika dengan santai dan nyaman.

9. "talk mathematics" atau berbicara matematika.

10. mengembangkan rasa tanggung jawab atas keberhasilan dan kegagalan diri sendiri.

Salah satu cara yang direkomendasikan Freedman pada butir ke-enam adalah belajar matematika dengan menggunakan gaya belajar sendiri. Jelas, setiap mahasiswa pasti berbeda dengan mahasiswa lainnya. Begitu pula dengan gaya belajar, tidak semuanya seragam. Seorang mahasiswa dapat saja memiliki tipe belajar visual, reading, audio atau kinestetik. Gaya belajar mahasiswa inilah yang menjadi salah satu dasar membedakan intruksi dalam pendekatan DI. Dalam pendekatan DI, gaya belajar mahasiswa yang berbeda-beda ini justru dijadikan kekuatan mahasiswa dalam belajar matematika. Sehingga dapat dikatakan pendekatan DI ini secara tidak langsung dapat mengurangi kecemasan matematika mahasiswa. 
Penelitian Benner (2010) menyimpulkan bahwa kecemasan matematika bukanlah reaksi terhadap matematika itu sendiri, melainkan sebuah hasil dari kelas matematika. Hal ini berarti seorang guru berada dalam posisi yang unik untuk mencegah perkembangan kecemasan matematika. Pernyataan ini menjelaskan bahwa guru bertanggung jawab untuk mengkondisikan kelas matematika sebagaimana yang diharapkan. Yaitu situasi yang dapat mencegah berkembangnya kecemasan matematika pada diri mahasiswa. Penegasan akan peran guru dalam kecemasan matematika mahasiswa ini dinyatakan dalam penelitian Plaisance (2010). Dikatakan bahwa cara guru dalam mengajarkan materi menjadi alasan bagaimana tingkat kecemasan matematika mahasiswanya.

\section{METODE PENELITIAN}

Penelitian ini menggunakan jenis Penelitian Tindakan (Action Research). Penelitian ini dilaksanakan di kelas VII-D SMPN 1 Ciruas Kabupaten Serang, pada semester ganjil tahun ajaran 2019-2020 yang dimulai pada bulan Juli hingga September 2019. Teknik analis data yang dikumpulkan data kuantitatif dengan pengolahan data statistik sederhana dan konsep bilangan menjadi kajian pada penelitian ini.Subjek penelitian adalah siswa kelas VII-D SMPN 1 Ciruas yang terdiri atas 14 peserta didik laki-laki dan 18 peserta didik perempuan. Penelitian ini juga dibantu oleh seorang rekan guru yang berperan sebagai observer untuk mengamati proses jalannya penelitian.

Model PTK menggunakan Model John Elliot, di mana setiap langkah penelitian dilaksanakan dengan lebih detail dan rinci. Dikatakan demikian, karena di dalam setiap siklus terdiri dari beberapa aksi atau tindakan. Sementara itu, setiap aksi juga terdiri dari beberapa langkah, yang terealisasi dalam bentuk kegiatan belajar mengajar. Secara garis besar terdapat empat tahapan model penelitian, yaitu : (1) perencanaan, (2) pelaksanaan, (3) pengamatan dan (4) refleksi. Hasil refleksi kemudian dipergunakan untuk perencanaan siklus berikutnya. Model John Elliot, karena di dalam setiap siklus dimungkinkan terdiri dari beberapa aksi yaitu antara 3-5 aksi (tindakan). Sementara itu, setiap aksi kemungkinan terdiri dari beberapa langkah, yang terealisasi dalam bentuk kegiatan belajar-mengajar.

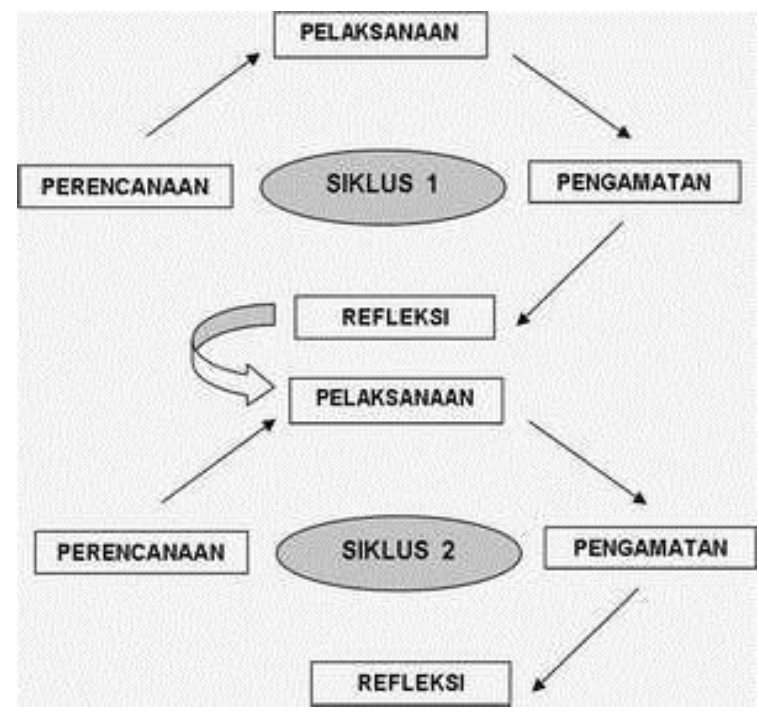

Gambar 1. Model John Elliot 
Untuk pengumpulan data dalam penelitian ini, peneliti membuat beberapa instrumen yaitu :

1. Tes

Tes hasil belajar untuk mengukur sejauh mana peningkatan penalaran siswa dalam konsep bilangan materi bilangan bulat. Tes dilaksanakan di akhir siklus.

2. Lembar Kerja Kelompok

Lembar kerja berupa hasil karya/produk merupakan bentuk Discovery Learning yang dibuat oleh peserta didik untuk mengukur kreativitas peserta didik.

3. Lembar Observasi

Lembar observasi ini digunakan untuk mengetahui aktivitas guru dan peserta didik selama proses pembelajaran berlangsung materi bilngan bulat.

4. Angket Siswa

Angket siswa digunakan untuk mengetahui respon dan tanggapan peserta didik terhadap kecemasan matematis pada konsep bilangan.

\section{HASIL DAN PEMBAHASAN}

Discovery Learning

Pelaksanaan penelitian peningkatan keaktifan dan hasil belajar bilangan, siswa kelas VII D SMPN 1 Ciruas menggunakan model Discovery Learning ini dilaksanakan melalui 2 siklus. Secara garis besar penggunaan model Discovery Learning mampu meningkatkan keaktifan dan hasil belajar siswa. Hasil pengamatan yang dilakukan oleh peneliti menyimpulkan bahwa keaktifan belajar siswa mengalami peningkatan selama proses pembelajaran. Peningkatan keaktifan belajar berdampak pada peningkatan hasil belajar siswa. Peningkatan keaktifan siswa dan hasil belajar bilangan pada siswa kelas VII D SMPN 1 Ciruas dalam pembelajaran matematika, tindakan siklus I sampai tindakan siklus II disajikan dalam Tabel 1.

Tabel 1.Peningkatan hasil belajar Discovery Leaning, Siklus I, dan Siklus II

\begin{tabular}{clll}
\hline \multicolumn{1}{c}{$\begin{array}{c}\text { Aspek yang } \\
\text { diamati }\end{array}$} & \multicolumn{1}{c}{ Indikator } & Siklus I & \multicolumn{1}{c}{ Siklus II } \\
\hline Keaktifan belajar & siswa bertanya & $72 \%$ & $86 \%$ \\
& siswa menjawab pertanyaan & $55 \%$ & $83 \%$ \\
& $\begin{array}{l}\text { siswa berani } \\
\text { mempresentasikan jawaban }\end{array}$ & $62 \%$ & $76 \%$ \\
& $\begin{array}{l}\text { di depan kelas } \\
\text { siswa menanggapi pendapat }\end{array}$ & $52 \%$ & $79 \%$ \\
& $\begin{array}{l}\text { siswa lain } \\
\text { Siswa yang mencapai KKM } \\
\text { Hasil belajar }\end{array}$ & $76 \%$ & $90 \%$ \\
\hline
\end{tabular}

Pada pelaksanaan tindakan siklus I terjadi peningkatan keaktifan dan hasil belajar siswa, tetapi masih belum memuaskan. Pencapaian keaktifan belajar siswa pada pelaksanaan tindakan siklus I yaitu: siswa bertanya 72\% (23 siswa), siswa menjawab pertanyaan 55\% (17 siswa), siswa berani mempresentasikan jawaban di depan kelas $62 \%$ (20 siswa), siswa menanggapi pendapat siswa lain 52\% (17 siswa), dan hanya $76 \%$ (24 siswa) siswa yang mencapai $\mathrm{KKM} \geq 70$. Berdasarkan hasil refleksi, peneliti menyimpulkan bahwa tindakan kelas pada siklus I ini belum mengalami peningkatan yang signifikan, dilihat dari belum tercapainya dua indikator keaktifan yaitu siswa menjawab pertanyaan dan siswa berani 
menanggapi pendapat siswa lain, sehingga berdampak pada hasil belajar siswa. Hal-hal yang diperbaiki untuk pelaksanaan siklus selanjutnya antara lain: (1) Pada awal pembelajaran guru menekankan kepada siswa bahwa keaktifan siswa juga dinilai dalam pembelajaran; (2) Guru memberikan pertanyaan yang merangsang siswa untuk lebih aktif dalam bertanya dan mengemukakan pendapat; (3) Guru memberikan kesempatan yang sama pada siswa untuk bertanya, menjawab pertanyaan, dan memberikan tanggapan.

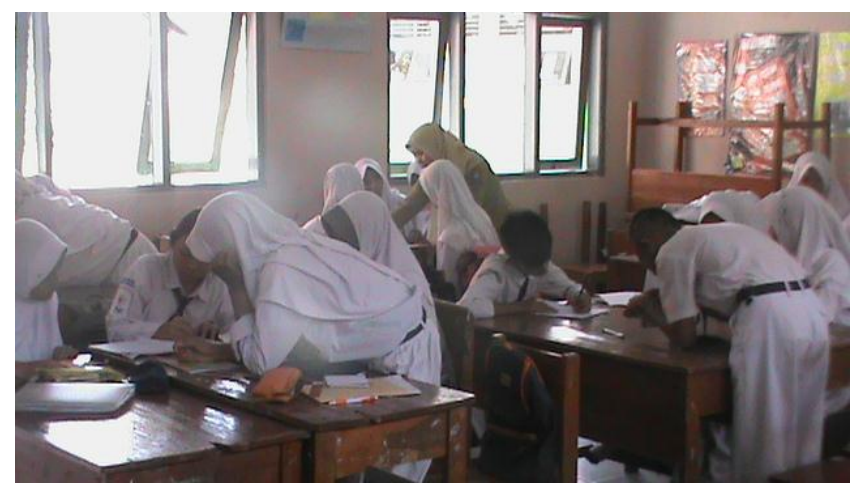

Gambar 2. Diskusi kelompok kegiatan praktek di kelas pada materi bilangan

Pada pelaksanaan tindakan siklus II diperoleh data siswa bertanya 86\% (27 Siswa), siswa menjawab pertanyaan $83 \%$ (26 siswa), siswa berani mempresentasikan jawaban di depan kelas 76\% (24 siswa), siswa menanggapi pendapat siswa lain 79\% (25 siswa), dan siswa mencapai $\mathrm{KKM} \geq 70$ yaitu $90 \%$ (29 siswa). Penerapan model pembelajaran Discovery Learning berjalan dengan lancar dan sesuai dengan RPP siklus II. Siswa sudah memiliki kesadaran bahwa dengan bertanya siswa dapat mengetahui dan memahami materi yang masih dianggap sulit. Selain itu, siswa sudah berani untuk menanggapi pendapat siswa lain. Peningkatan indikator keaktifan pada siklus II mendorong peningkatan hasil belajar bilangan siswa pada pembelajaran matematika. Pada siklus II ini indikator hasil belajar siswa yaitu siswa mencapai KKM $\geq 70$ sudah tercapai yaitu 90\% (29 siswa). Berdasarkan refleksi siklus II, peneliti mengambil keputusan bahwa tindakan kelas dengan model pembelajaran Discovery Learning berakhir pada siklus II.

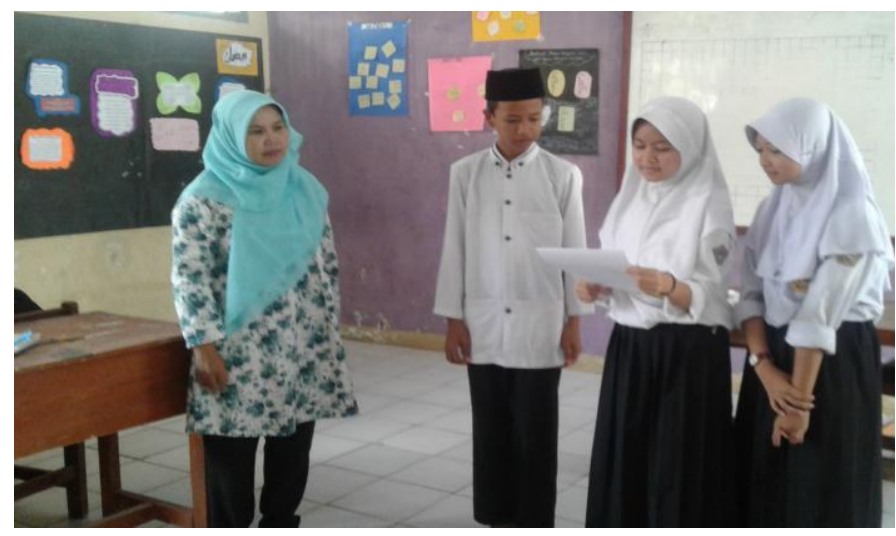

Gambar 3. Mempresentasikan jawaban di depan kelas 


\section{Kecemasan Matematis}

Kecemasan matematis diidentifikasi dengan 8 Indikator yang terdiri dari 30 butir pernyataan menurut Gupitasari ( 2015).

Tabel 2. Kisi - kisi Skala Kecemasan Matematis Siswa

\begin{tabular}{ll}
\hline \multicolumn{1}{c}{ Kriteria } & \multicolumn{1}{c}{ Aspek yang diukur } \\
\hline Kecemasan ketika belajar & Somatik \\
matematika & Kognitif \\
Kecemasan ketika mengeikuti & Sikap \\
tes matematika & Pengetahuan Matematika \\
\hline
\end{tabular}

Pengolahan kecemasan matematis dengan MSI (Method Of Succesive Interval) mentransformasi data beskala ordinal menjadi data beskala interval.

Tabel 3. Penurunan Kecemasan Matematis, Siklus I, dan Siklus II

\begin{tabular}{ccc}
\hline Siklus & Siklus I & Siklus II \\
\hline Rata-Rata & 71 & 65 \\
\hline
\end{tabular}

Pada pelaksanaan tindakan siklus I terjadi kecemasan matematis rata-rata masih 71 berdasarkan hasil refleksi, peneliti menyimpulkan bahwa tindakan kelas pada siklus I ini belum mengalami penurunan yang signifikan, Pada pelaksanaan siklus II terjadi penurunan kecemasan matematis menjadi 65. Berdasarkan refleksi siklus II,penurunan kecemasan matematis $8,5 \%$.

Berdasarkan pelaksanaan penelitian pembelajaran matematika menggunakan model Discovery Learning, Peneliti menemukan kelebihan dan kekurangan dari penggunaan model Discovery Learning. Kelebihan model Discovery Learning yaitu: (1) Mendorong siswa untuk belajar aktif secara mandiri dan kolaboratif dengan bekerja secara kelompok; (2) Menumbuhkembangkan kreativitas guru dalam mengimprovisasi dan mengembangkan kegiatan pembelajaran. Kekurangan model Discovery Learning (1) Penerapan model Discovery Learning memerlukan persiapan yang matang oleh guru mulai dari penyusunan RPP, penguasaan materi hingga hingga kegiatan pembelajaran; (2) Dipelukan managemen waktu yang baik agar penerapan model Discovery Learning berjalan dengan efektif dan efisien

\section{SIMPULAN DAN SARAN}

Berdasarkan hasil penelitian dan pembahasan dengan metode Discovery Learning. dapat disimpulkan bahwa pembelajaran matematika dengan model Discovery Leaning berpengaruh positif terhadap penurunan kecemasan matematis siswa. Aktivitas siswa selama pembelajaran dengan menggunakan model pembelajaran Discovery Learning pada konsep Bilangan meningkat pada setiap siklusnya yang ditunjukkan dengan partisipasi aktif siswa, bekerjasama pada tiaptiap kelompoknya masing-masing di setiap siklusnya.

1. Model pembelajaran discovery dapat dijadikan sebagai alternatif model pembelajaran yang dapat mempengaruhi kecemasan matematis siswa, bahkan berdasarkan temuan hasil penelitian bahwa model pembelajaran discovery dapat menurunkan kecemasan siswa.

2. Merancang kegiatan pembelajaran yang mampu mengembangkan kompetensi baik dalam ranah kognitif, afektif maupun psikomotor siswa, strategi pembelajaran yang berpusat pada siswa. 
3. Menggunakan berbagai model dan metode pembelajaran agar proses pembelajaran berlangsung dengan aktif, kreatif, dan menyenangkan

\section{DAFTAR RUJUKAN}

Amir, J. \&. (2015). Psikologi Pembelajaran Matematika. Yogyakarta: Aswaja Pressindo.

Amir, Z. D. (2015). Psikologi Pembelajaran Matematika (1st ed., p. 218). Yogyakarta: Aswaja Pressindo.

Anis W, Y. (2017). Peningkatan Kemandirian dan Hasil Belajar IPS Menggunakan Model Discovery Learning di Kelas VIII SMP, Jurnal Pendidikan Matematika. Vol.3(2): 10 halaman :15-24.

Anita, W. I. (2011). Pengaruh Kecemasan (Mathematics Anxienty) terhadap kemampuan pemecahan masalah dan koneksi matematika siswa smp. Tesis tidak di terbitkan. UPI Bandung.

Ashcraft, M.H. (2002). "Math Anxiety: Personal, Educational, and Cognitive Consequences". Directions in Psychological Science. 11.

Benner, J. (2010). Anxiety in The Math Classroom. Bemidji State University. Tesis. Tidak Diterbitkan.

Davis, S. (2012). Student's Math Anxiety Bill of Right. [Online]. Tersedia: http://www.mathpower.com/billrght2.htm [ 17 Desember 2012].

Fox, J. \& Hoffman, W. (2011). The Differentiated Instruction Book of Lists. San Fransisco. Jossey-Bass. [Online]. Tersedia: http://books.google.co.id/books?id=W93R_tO49zYC\&printsec=frontcover $\& \mathrm{hl}=\mathrm{id} \# \mathrm{v}=$ onepage $\& \mathrm{q} \& \mathrm{f}=$ false [3 Oktober 2012]

Greshman, G. (2010). "A Study Exploring exceptional Education Pre_Servis Theacher' Mathematic Anxienty". UIMPST : jurnal.vol 4.".

Gupitasari, G. (2015). Penurunan Kecemasan dan Peningkatan Kemampuan Berpikir Kritis Matematis Siswa SMP Melalui Model Pembelajaran Knisnely. Retrived from Universitas Pendidikan Indonesia Irepository.upi.edul.perpustakaan.upi.edu.

Heriawan, A. D. (2012). Metodologi Pembelajaran Kajian Teoritis Praktis. (S. Iskandar, Ed.). Serang-Banten: Lembaga Pembinaan dan Pengembangan Profesi Guru.

Mentari, W. (2015). Pengaruh Model Discovery Learning Terhadap Kemampuan Berpikir Kritis dan Hasil Belajar Siswa.

Plaisance, D.V. (2009). "Mathematics Anxiety of Preservice Elementary Teachers After Completing a Problem Solving Course". Louisiana Association of Teachers (LATM) Journal, 5, (1).

Rohani, A. (2010). Pengelolaan Pengajaran. Jakarta: PT.Rineka Cipta.

Sagala, S. (. (2013). Konsep dan Makna Pembelajaran. Bandung: Alfabeta.

Sani, R. A. (2016). Inovasi Pembelajaran. (Y. S. Hayati, Ed.) (4th ed.). Jakarta: PT. Bumi Aksara.

Sumarmo, U. (2015). Kumpulan Makalah: Berpikir Dan Disposisi Matematik Serta Pembelajarannya. (D. S. Dkk, Ed.) (1st ed.). Bandung: FPMIPA UPI.

Yusmanto, T. (2013). Pengaruh Penerapan Model Pembelajaran Discovery Learning Terhadap Peningkatan Kemampuan Berfikir Kritis Matematis dan Self Confodence Siswa Kelas V Sekolah Dasar. Tesis Magister pada Fakultas Pascasarjana UPI. Tersedia. 